\title{
Characterization of sulfhydryl oxidase from Aspergillus tubingensis
}

\author{
Outi Nivala ${ }^{1 *}$, Greta Faccio ${ }^{1,2}$, Mikko Arvas ${ }^{1}$, Perttu Permi ${ }^{3,4,5}$, Johanna Buchert ${ }^{1,6}$, Kristiina Kruus $^{1}$ \\ and Maija-Liisa Mattinen ${ }^{1,7}$
}

\begin{abstract}
Background: Despite of the presence of sulfhydryl oxidases (SOXs) in the secretomes of industrially relevant organisms and their many potential applications, only few of these enzymes have been biochemically characterized. In addition, basic functions of most of the SOX enzymes reported so far are not fully understood. In particular, the physiological role of secreted fungal SOXs is unclear.

Results: The recently identified SOX from Aspergillus tubingensis (AtSOX) was produced, purified and characterized in the present work. AtSOX had a pH optimum of 6.5 , and showed a good pH stability retaining more than $80 \%$ of the initial activity in a pH range $4-8.5$ within $20 \mathrm{~h}$. More than $70 \%$ of the initial activity was retained after incubation at $50{ }^{\circ} \mathrm{C}$ for $20 \mathrm{~h}$. AtSOX contains a non-covalently bound flavin cofactor. The enzyme oxidised a sulfhydryl group of glutathione to form a disulfide bond, as verified by nuclear magnetic resonance spectroscopy. AtSOX preferred glutathione as a substrate over cysteine and dithiothreitol. The activity of the enzyme was totally inhibited by $10 \mathrm{mM}$ zinc sulphate. Peptide- and protein-bound sulfhydryl groups in bikunin, gliotoxin, holomycin, insulin B chain, and ribonuclease A, were not oxidised by the enzyme. Based on the analysis of 33 fungal genomes, SOX enzyme encoding genes were found close to nonribosomal peptide synthetases (NRPS) but not with polyketide synthases (PKS). In the phylogenetic tree, constructed from 25 SOX and thioredoxin reductase sequences from IPR000103 InterPro family, AtSOX was evolutionary closely related to other Aspergillus SOXs. Oxidoreductases involved in the maturation of nonribosomal peptides of fungal and bacterial origin, namely GliT, HIml and DepH, were also evolutionary closely related to AtSOX whereas fungal thioreductases were more distant.

Conclusions: AtSOX ( $55 \mathrm{kDa}$ ) is a fungal secreted flavin-dependent enzyme with good stability to both $\mathrm{pH}$ and temperature. A Michaelis-Menten behaviour was observed with reduced glutathione as a substrate. Based on the location of SOX enzyme encoding genes close to NRPSs, SOXs could be involved in the secondary metabolism and act as an accessory enzyme in the production of nonribosomal peptides.
\end{abstract}

Keywords: Secreted sulfhydryl oxidase, Dithiol oxidase, Aspergillus tubingensis, Glutathione oxidation, Nonribosomal peptide synthesis, Secondary metabolism

\section{Background}

Sulfhydryl oxidases (SOXs) are flavin-dependent enzymes that catalyse the oxidation of free thiol groups to disulfide bonds with the concomitant reduction of molecular oxygen to hydrogen peroxide. SOXs have been isolated from animal and microbial sources [1-4]. Both intracellular and secreted enzymes have been reported [5-9]. SOX enzymes can be classified to four major families based on their

\footnotetext{
*Correspondence: outi.nivala@helsinki.fi

${ }^{1} \mathrm{VTT}$ Technical Research Centre of Finland, Ltd., P.O. Box 1000, FI-02044

Espoo, Finland

Full list of author information is available at the end of the article
}

structural features: intracellular single-domain proteins essential for respiration and vegetative growth / augmenter of liver regeneration (the Erv/Alr family), the endoplasmic reticulum oxidase (Ero) family, the quiescin-sulfhydryl oxidase (QSOX) family with multi-domain enzymes, and the secreted fungal SOXs family with FAD-dependent dimeric single-domain enzymes (reviewed in [10]). The secreted fungal SOXs differ from the members in other SOX families. They carry features from thioredoxin reductase and pyridine nucleotide flavin disulphide oxidoreductase sequences [10]. Many fungal species such as Aspergillus niger, Penicillium chrysogenum, Aspergillus 
oryzae, Aspergillus sojae, and Calodon sp. have been reported to secrete SOXs (glutathione oxidase EC 1.8.3.3) $[1,3,5,6,10,11]$. Numerous SOX-coding genes have been found in the genome of fungi. The genome of the yeast Saccharomyces cerevisiae contains two putative genes encoding SOX enzymes, while so far published genomes of the fungal genus Aspergilli typically contain from 10 to 12 putative genes encoding SOX enzymes [12]. The genome of $A$. tubingensis contains genes encoding eight putative SOXs [13].

SOXs are attractive catalysts for industrial applications. They have been tested in food applications such as in dairy and baking. SOXs have been used for ultra-high temperature (UHT)-treated milk to remove of unpleasant flavour [6, 14]. In baking, SOX enzymes have been utilized to strengthen the structure of dough and improving bread properties [15-17]. SOXs have been suggested to reduce the allergenicity of pharmaceuticals [18]. The characterized fungal SOXs are known to crosslink bonds between peptides but not between proteins $[1,3,19]$. There occurs variation in the substrate specificity within SOXs from different sources. The small thiol-containing molecules are typical substrates for secreted fungal SOXs, whereas mammalian bovine SOXs are known to oxidase protein-bound cysteine residues $[1,10,20]$. The function of intracellular S. cerevisiae SOXs and of some multi-domain SOXs is elucidated but the role for secreted fungal SOXs is still unclear $[7,21]$. The sectered fungal SOXs do not form a mixed disulphide intermediate on the contrary to the mammalian SOXs and intracellular S. cerevisiae SOXs (Erv1p, Erv2p) [22-24], which implies that secreted fungal SOXs are not directly involved in the oxization of the reduced proteins. Multi-domain SOXs from the quiescinsulfhydryl oxidase (QSOX) family have been proposed to be involved in the formation of the extracellular matrix, in the maturation of proteins along the secretory pathway, and to act as antimicrobial agent $[4,21,25,26]$. Extracellular QSOXs are multi-domain sulfhydryl oxidases from multicellular organisms, and greatly differ from the singledomain secreted fungal SOXs. The QSOX and secreted fungal SOX proteins belong to different protein families and appear to be evolutionary unrelated. In bacteria, SOXs might be involved in the synthesis of bioactive compounds such as nonribosomal peptides [27].

This paper reports the biochemical characterization of SOX from $A$. tubingensis (AtSOX) previously identified in the screening study [28]. AtSOX was purified and its substrate specificity was further characterized and its activity on different peptide- and protein-bound sulfhydryl groups analysed. The formation of enzyme-catalysed disulphide bond in glutathione was confirmed by NMR spectroscopy. Furthermore, 33 fungal genomes were analysed to examine location of the selected genes, for example nonribosomal peptide synthetase or polyketide synthase coding genes, in relation to SOX-coding genes.

\section{Methods \\ Production and purification of AtSOX}

Aspergillus tubingensis strain D-85248 was obtained from the VTT Culture Collection [29] and cultivated as described in [28]. A. tubingensis was grown on PeptoneTM$\mathrm{D}(+)$-glucose media adapted from $[3,5]$ in liquid cultivation at $30{ }^{\circ} \mathrm{C}$ under shaking $(250 \mathrm{rpm})$. After removal of the fungal biomass by filtration, AtSOX was purified from the cell-free extract with four chromatographic steps according to the procedure described below. The culture supernatant was concentrated and buffer exchanged to $20 \mathrm{mM}$ Tris$\mathrm{HCl} \mathrm{pH} 7$ with a PD10 column (no 17-0851-01, GE Healthcare, Uppsala, Sweden), and applied on a QSepharose fast flow column (volume $=20 \mathrm{~mL}$, Amersham Biosciences, Piscataway, USA). Proteins were eluted with a linear gradient from 0 to $0.3 \mathrm{M} \mathrm{NaCl}$ in $20 \mathrm{mM}$ Tris- $\mathrm{HCl} \mathrm{pH} \mathrm{7.} \mathrm{The}$ SOX activity of the fractions was detected using 5,5-dithiobis(2-nitrobenzoic acid) (Ellman's reagent, DTNB, no D 218200, Sigma-Aldrich, Helsinki, Finland) and oxygen consumption measurements. The SOX active fractions were pooled and applied to a Superdex 75 column (volume $=$ $24 \mathrm{~mL}$, Amersham Biosciences, USA) using $50 \mathrm{mM}$ Tris$\mathrm{HCl} \mathrm{pH} 7$ buffer containing $150 \mathrm{mM} \mathrm{NaCl}$ at a $0.1 \mathrm{~mL} / \mathrm{min}$ flow rate. SOX-active fractions were pooled, concentrated, buffer exchanged to $20 \mathrm{mM}$ Tris- $\mathrm{HCl} \mathrm{pH} \mathrm{7,} \mathrm{and} \mathrm{applied}$ twice to a Resource Q Sepharose column (volume $=1 \mathrm{~mL}$, Amersham Biosciences, USA). In the first separation using Resource Q Sepharose resin, the proteins were eluted with a linear gradient from 0 to $0.2 \mathrm{M} \mathrm{NaCl}$ in $20 \mathrm{mM}$ Tris$\mathrm{HCl} \mathrm{pH} \mathrm{7,} \mathrm{whereas} \mathrm{in} \mathrm{the} \mathrm{second} \mathrm{separation} \mathrm{a} \mathrm{shallower}$ gradient from 0 to $0.11 \mathrm{M} \mathrm{NaCl}$ was used. Prepacked anion exchange columns were connected to ÄKTA ${ }^{\text {mo }}$ chromatography system and UNICORN Control Software (GE Healthcare, Uppsala, Sweden).

Protein concentration was determined using a Bio-Rad DC protein assay kit (Bio-Rad, Hercules, USA) and bovine serum albumin (BSA, no. A8022, Sigma, St. Louis, USA) as a standard. Proteins were analysed by readymade 12\% Tris-HCl SDS-PAGE gel (no 161-1156, BioRad, Hercules, USA) to ensure purity of the isolated AtSOX enzyme.

\section{Amino acid analysis of AtSOX and strain identification}

The partial amino acid sequence of AtSOX was determined from the $\mathrm{N}$-terminus and internal peptide fragments. SDS-PAGE protein bands were stained with Coomassie Brilliant Blue, and the protein band of interest was excised and subjected to $\mathrm{N}$-terminal sequencing. Edman degradation was performed using a Procise 494A protein sequencer from Perkin Elmer, Applied Biosystems Division (Foster City, CA, USA). The Coomassie 
stained protein band, assumably containing AtSOX, was cut off from the SDS-PAGE and in gel digested essentially as described by [30] for obtaining internal sequences and for peptide mass fingerprinting (PMF). In gel digestion was done by reducing proteins with dithiothreitol (DTT), alkylating with iodoacetamide and digesting with trypsin (no V5111, Promega, Madison, USA). The enzymatic cleavage occurred during overnight incubation at $37{ }^{\circ} \mathrm{C}$. The peptides produced by enzymatic cleavage were analysed by MALDI-TOF MS after desalting using $\mathrm{mC} 18$ ZipTip (no ZTC18M096, Millipore, Billerica, USA). MALDI-TOF mass spectra of peptide fragments for PMF were obtained using an Ultraflex TOF/TOF instrument (Bruker-Daltonik GmbH, Bremen, Germany) using $\alpha$ cyano-4-hydroxycinnamic acid (CHCA) as matrix. The sample solution was pipetted onto the sample plate together with matrix and air-dried. An electrospray ionization quadrupole time-of-flight tandem mass spectra for de novo sequencing were acquired using a Q-TOF instrument (Micromass, Manchester, UK) as described by [31]. Protein identification with the generated data, the obtained peptide masses and the partial sequences, was performed using the Mascot Peptide Mass Fingerprint and MS/MS Ion Search programmes (http://www.matrixscience.com). Identification of the production strain (VTT D-85248) based on the morphology and DNA sequencing was performed at the Identification Services CBS (Utrecht, The Netherlands).

\section{Peptide and protein substrate preparation}

The reduced glutathione (GSH, no G4251), urinary trypsin inhibitor fragment (bikunin, no U-4751), and ribonuclease A (RNase A, no R5500) were purchased from Sigma (St. Louis, USA). Peptides, gliotoxin (no. A7665) and holomycin (no. sc-49,029), were purchased from PanReac AppliChem GmbH (Darmstadt, Germany) and Santa Cruz Biotechnology Inc. (Dallas, USA), respectively. The insulin $B$ chain as Bunte salt derivative was kindly provided by Dr. Elisabeth Heine from Deutsches Wollforschungsinstitut (DWI, Aachen, Germany). Insulin chain B and RNaseA were reduced before use with $3 \%(\mathrm{v}: \mathrm{v}) 2$-mercaptoethanol in the presence of $8 \mathrm{M}$ urea according to the method used by [3]. For the reduction, insulin $\mathrm{B}$ was dissolved in $50 \mathrm{mM}\left(\mathrm{NH}_{4}\right) \mathrm{HCO}_{3} \mathrm{pH} 8.3$ containing $8 \mathrm{M}$ urea and $3 \%(\mathrm{v}: \mathrm{v})$ 2-mercaptoethanol was used as solvent. In the case of RNaseA, $200 \mathrm{mM}$ Tris$\mathrm{HCl}$ buffer ( $\mathrm{pH}$ 7.4) with urea and 2-mercaptoethanol was used. The solutions were incubated overnight at room temperature. The final concentration of insulin chain B was $1 \mathrm{mM}$, and concentration of RNaseA was $0.5 \mathrm{mM}$. After reduction the free sulfhydryl groups were detected with 5,5-dithio-bis(2-nitrobenzoic acid). Gliotoxin and holomycin were reduced with two equivalence of Tris(2carboxyethyl)phosphine hydrochloride (TCEP-HCl) under nitrogen flow for $1 \mathrm{~h}$ prior liquid chromatography mass spectrometry (LC-MS) analysis.

\section{Assay of AtSOX activity and $\mathrm{pH}$ and temperature behaviour}

Different methods were used to measure AtSOX activity. First DTNB [32] was used for the detection of free sulfhydryl groups in the peptides after the enzymatic reaction. The spectroscopic measurements were done with a Cary 100 Bio UV-vis spectrophotometer (Varian Inc., Houten, the Netherlands). Second, the oxygen consumption measurement with Fibox 3 PreSens fiber-optic oxygen meter (Presens GmbH, Regensburg, Germany) was used to measure the changes in the concentration of dissolved oxygen during enzymatic reaction as described by [28] GSH (5 mM) was used as a substrate when determining AtSOX activity. The substrate was dissolved in phosphate buffered saline (PBS) containing $68 \mathrm{mM} \mathrm{NaCl}$ and $75 \mathrm{mM}$ $\mathrm{KH}_{2} \mathrm{PO}_{4} \mathrm{pH}$ 7.4. Activity of AtSOX was measured by the oxygen consumption assay in the presence of different GSH concentrations $(0.25-10 \mathrm{mM})$ to determine the kinetic parameters. The Michaelis-Menten constant $\left(\mathrm{K}_{\mathrm{m}}\right)$ and maximum velocity $\left(\mathrm{V}_{\max }\right)$ were determined with graphing software GraphPad Prism (GraphPad Software Inc., San Diego, USA) using nonlinear curve fitting to the Michaelis-Menten equation.

The thermal stability of AtSOX was determined at 30, 40, 50, 60 and $70{ }^{\circ} \mathrm{C}$. The enzyme preparation was incubated in Mcllvaine buffer $\mathrm{pH} 6.5 \mathrm{in}$ a $0.2 \mathrm{mg} / \mathrm{mL}$ protein concentration for $1,2,15.5$ and $20 \mathrm{~h}$ at $30-70{ }^{\circ} \mathrm{C}$ and also for $15 \mathrm{~min}$ at $70{ }^{\circ} \mathrm{C}$, and the residual activity was measured by the oxygen consumption assay. $\mathrm{pH}$ stability was determined for AtSOX in a pH range between 2.3 and 10 , and the residual enzyme activity was analysed by the oxygen consumption assay after 1 and $20 \mathrm{~h}$ incubation. $\mathrm{pH}$ optimum was determined by measuring AtSOX activity with the oxygen consumption assay using glutathione in Mcllvaine citrate/phosphate buffer ( $\mathrm{pH}$ 2.3-7.5), $50 \mathrm{mM}$ Tris- $\mathrm{HCl}(\mathrm{pH} 7-9)$ and $50 \mathrm{mM}$ Glycine- $\mathrm{NaOH}$ (pH 8.5-10).

\section{Spectroscopy measurements}

UV-vis absorption spectra were measured in $20 \mathrm{mM}$ Tris$\mathrm{HCl} \mathrm{pH} 7.5$ at $20^{\circ} \mathrm{C}$ using a Cary $100 / 300 \mathrm{UV}$-vis spectrophotometer (Varian Inc., Houten, the Netherlands). In order to release a flavin cofactor, enzyme was thermally denaturated at $100{ }^{\circ} \mathrm{C}$ for $15 \mathrm{~min}$ followed by centrifugation (13,000 rpm, $10 \mathrm{~min})$. Fluorescence was measured at $20{ }^{\circ} \mathrm{C}$ with a Cary Eclipse Fluorescence Spectrophotometer (Varian Inc., Houten, the Netherlands) using AtSOX solution in $20 \mathrm{mM}$ Tris- $\mathrm{HCl} \mathrm{pH} 7.5$ in quartz cuvette with four optical faces. FAD fluorescence was recorded by exciting at $450 \mathrm{~nm}$ and monitoring emission between 450 and $600 \mathrm{~nm}$. 


\section{Inhibition analysis of AtSOX}

The AtSOX activity was analysed in a buffer solution and in the presence of different inhibitors. The effect of possible inhibitors on the AtSOX activity was determined using $5 \mathrm{mM}$ GSH as substrate. The tested potential inhibitors were DTT, ethylenediaminetetraacetic acid (EDTA), potassium iodide, magnesium sulphate, manganese sulphate, sodium sulphate, sodium chloride, zinc sulphate, and sodium dodecyl sulphate (SDS). The inhibitors were tested at $10 \mathrm{mM}$ concentration in $200 \mathrm{mM}$ Tris- $\mathrm{HCl}$ buffer $\mathrm{pH}$ 7.5, and zinc sulphate was tested also at $1 \mathrm{mM}$ concentration. The residual SOX activity was measured by oxygen consumption measurements (Fibox 3 PreSens fiber-optic oxygen meter, PreSens $\mathrm{GmbH}$, Regensburg, Germany). Inhibition by zinc sulphate was confirmed by homovanillic acid (HVA) and peroxidase coupled assay as described in [33], and the assay was done according to [34] using GSH (5 mM) as a substrate. Chemicals, HVA (Cat. no. H1252) and peroxidase type II (Cat. no. P8250), were purchased from Sigma-Aldrich (St. Louis, USA). Fluorescence from the production of a HVA dimer was measured in a black 96well microtiter plate at $320 \mathrm{~nm}$ excitation and $420 \mathrm{~nm}$ emission wavelengths using a Varioskan spectral scanning multimode microplate reader (Thermo Electron co., Vantaa, Finland).

\section{Activity of AtSOX with reduced peptides}

The ability of AtSOX to oxidise the peptides carrying free sulfhydryl groups was analysed by following the oxygen consumption. The activity of AtSOX (112 nkat) was analysed using reduced RNase A $(0.25 \mathrm{mM}$ solution in $200 \mathrm{mM}$ Tris- $\mathrm{HCl} \mathrm{pH} \mathrm{7.4),} \mathrm{and} \mathrm{reduced} \mathrm{GSH} \mathrm{(5} \mathrm{mM}$

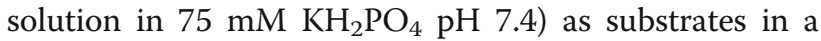
total $1.86 \mathrm{~mL}$ reaction volume. The enzyme reactions were monitored by following the oxygen consumption of the co-substrate. The reactions were performed at room temperature and monitored for 5-20 min. For NMR spectroscopy, the enzymatically treated GSH was prepared by incubating the substrate with AtSOX for 20 min while the dissolved oxygen was totally consumed, as assessed by oxygen consumption measurements. Freshly prepared and 3 day old GSH solutions ( $5 \mathrm{mM}$ ) were used as a control samples to assess possible autooxidation. Reaction mixtures were analysed with ${ }^{1} \mathrm{H}$ NMR as well as with ${ }^{13} \mathrm{C}$ heteronuclear single quantum correlation $\left({ }^{13} \mathrm{C}\right.$-HSQC $)$ spectroscopy. The enzyme treated sample and the control sample were prepared in $75 \mathrm{mM}$ potassium phosphate $\mathrm{pH} 7.4$ in Shigemi NMR tubes. The NMR spectra were recorded on Varian INOVA $600 \mathrm{MHz}$ NMR spectrometer at $293 \mathrm{~K}$. One dimensional ${ }^{1} \mathrm{H}$ spectra were recorded with water presaturation at $25{ }^{\circ} \mathrm{C}$ along with the gradient enhanced ${ }^{13} \mathrm{C}$-HSQC spectroscopy at $20{ }^{\circ} \mathrm{C}$ [35]. Homonuclear
Total Correlation Spectroscopy (TOCSY) experiments [36] were recorded to confirm the assignment.

Besides oxygen consumption method and NMR spectroscopy, the selected peptides were analysed with a MALDI-TOF MS on an Autoflex II spectrometer (Bruker Daltonik GmbH, Bremen, Germany) using CHCA matrix for peptides and sinapic acid (SA) for proteins. The reduced substrates GSH and insulin $\mathrm{B}$ were dissolved in

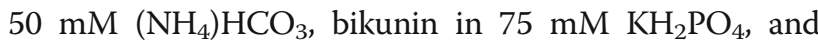
RNase A in 200 mM Tris- $\mathrm{HCl}$ pH 7.4. Purified SOX was used in the experiments in a dosage of 5.6 nkat $(4.1 \mu \mathrm{g}$ protein) and in case of insulin B and RNase A also in 56 nkat $(41 \mu \mathrm{g}$ protein). The enzymatic reactions were performed at $40{ }^{\circ} \mathrm{C}$, except for bikunin that was incubated at room temperature for $20 \mathrm{~h}$. Matrix solutions were prepared by dissolving CHCA or SA in a 1:1 solution of $0.1 \%$ trifluoroacetic acid and 100\% acetonitrile. The spots for MALDI plate were prepared by using 1:1 proportion of matrix and sample. Typically $1 \mu \mathrm{l}$ matrix and $1 \mu \mathrm{l}$ sample were used for MALDI spot, where matrix was spotted first and dried before adding sample.

Reduced gliotoxin and holomycin were used in $200 \mu \mathrm{M}$ final concentration in $0.1 \mathrm{M}$ phosphate buffer (pH 6.5) for spectroscopic measurements. Gliotoxin and holomycin were used in 440 and $680 \mu \mathrm{M}$ final concentrations, respectively, for LC-MS analysis. UV-vis absorption spectra from 200 to $600 \mathrm{~nm}$ were recorded with Varioskan spectral scanning multimode microplate reader (Thermo Electron co., Vantaa, Finland). The UVvis absorption spectra from 200 to $600 \mathrm{~nm}$ was recorded for $10 \mathrm{~min}$ before and after addition of AtSOX $(100 \mu \mathrm{l}$ reaction volume). Reduced peptides incubated (50 $\mathrm{min}$ at ambient temperature) with AtSOX or with denaturated AtSOX were analysed with a ultra performance LC (UPLC) combined with a photodiode array detector and SYNAPT G2-S High Definition Mass Spectrometry (Waters, Milford Massachusetts, USA). One microliter of the sample was injected to a LC pre-column. LC-MS system was using a C18 Acquity UPLC VanGuard precolumn $(2.1 \times 5 \mathrm{~mm}, 1.7 \mu \mathrm{m}$, $)$ and a C18 Acquity UPLC column $(2.1 \times 100 \mathrm{~mm}, 1.7 \mu \mathrm{m})$. All solvents used were spectral grade. Eluents were $5 \mathrm{mM}$ ammonium acetate $0.1 \%$ formic acid in $\mathrm{H}_{2} \mathrm{O}(\mathrm{A})$ and in methanol (B). Elution was started with $10 \% \mathrm{~B}$ for $1 \mathrm{~min}$, followed by a linear gradient from 10 to $100 \%$ B for 10 min and finally at $100 \% \mathrm{~B}$ for $2 \mathrm{~min}$, with $0.4 \mathrm{~mL} \mathrm{~min}^{-1}$ flow. In these conditions reduced gliotoxin eluted from the LC column after $5.23 \mathrm{~min}$ and gliotoxin standard after $6.02 \mathrm{~min}$. Elution times for reduced holomycin and holomycin standard were 1.69 and $3.74 \mathrm{~min}$, respectively.

\section{Analysis of SOX-coding genes in fungal genomes}

The search was carried out as described in [37]. In brief, scaffolds of 33 fungal genomes from [38] were divided in 
windows of 16 genes that overlapped with two genes. InterPro protein annotations of the genes were then used to look for windows that contained a flavin adenine dinucleotide (FAD)-dependent pyridine nucleotide-disulfide oxidoreductase (PNDR) that recognizes also SOX enzymes (InterPro: IPR000103), nonribosomal peptide synthetases (NRPS) (InterPro: IPR000873) or polyketide synthases (PKS) (InterPro: IPR001227) and cytochrome P450 monooxygenases (P450, InterPro: IPR001128) and/or Zn2Cys6 transcription factors (Zn2, InterPro: IPR001138). Searches were carried out and the results visualised with $R$ essentially as described by [38].

\section{Phylogenetic analysis}

A phylogenetic analysis of the selected 25 proteins from the protein family pyridine nucleotide-disulphide oxidoreductase, class-II (InterPro: IPR000103) was carried out. The selected protein sequences were obtained from UniProtKB except AtSOX sequence was retrieved from the genome of $A$. tubingensis from Joint Genome Institute (JGI) genome portal [39]. The alignment of the sequences was done with MAFFT [40], and alignment was trimmed with trimAl [41]. The aligned sequences were from Ascomycetes species except two proteins were bacterial origin, namely, DepH from Chromobacterium violaceum (UniProtKB: A4ZPY8) and HlmI from Streptomyces clavuligerus (UniProtKB: E2PZ87). A phylogenetic tree was constructed with FastTree [42] and visualised by Geneious version 10.0 created by Biomatters.

\section{Results}

Purification and biochemical characterization of AtSOX from Aspergillus tubingensis

Purification of AtSOX was performed in four chromatographic steps from the culture cell-free medium. Fractions containing SOX activity eluted at a $110-260 \mathrm{mM} \mathrm{NaCl}$ concentration from a Q Sepharose anion exchange column. Pooled active fractions were applied to a Superdex 75 column for separation by SEC. Further purification of AtSOX was achieved with high resolution anion exchange chromatography. The SOX containing fractions eluted at a $60-175 \mathrm{mM}$ and $100 \mathrm{mM} \mathrm{NaCl}$ concentration from two sequential purification steps where Resource Q columns were used. The fraction with the highest specific SOX activity was applied on a Resource Q column once again. AtSOX containing fractions started to elute at a $100 \mathrm{mM}$ $\mathrm{NaCl}$ concentration. The purification process was monitored by SDS-PAGE (Additional file 1), and the final yield of protein was $3 \%$ of the initial activity.

AtSOX preferred GSH $(3 \mathrm{mM})$ as a substrate over cysteine and DTT. AtSOX had residual activity on Lcystein $14 \pm 0.2 \%$, on D-cystein $3 \pm 1.2 \%$ and on DTT 9 $\pm 1.8 \%$ measured with oxygen consumption assay. Oxygen consumption in AtSOX-catalysed reaction using GSH ( $3 \mathrm{mM})$ as a substrate is shown in Additional file 2. Michaelis-Menten behaviour was observed for AtSOX using GSH as a substrate. Michaelis-Menten constant $\left(\mathrm{K}_{\mathrm{m}}\right)$ was $0.80 \pm 0.09 \mathrm{mM}$ and maximum velocity $\left(\mathrm{V}_{\max }\right)$ $(33.15 \pm 0.99) \times 108 \mathrm{nkat} / \mathrm{ml}$ (Fig. 1a). AtSOX retained $89 \%$ of the initial activity after $20 \mathrm{~h}$ incubation at $40{ }^{\circ} \mathrm{C}$ (Fig. 1c). Under identical conditions at 50 and $60{ }^{\circ} \mathrm{C}$, AtSOX showed $75 \%$ and $18 \%$ residual activity, respectively. At $70{ }^{\circ} \mathrm{C}$, the enzyme was inactivated within 15 min. AtSOX was stable within a broad $\mathrm{pH}$ range as it retained $80-90 \%$ of the initial activity after $20 \mathrm{~h}$ incubation at $\mathrm{pH}$ range from 4 to 8.5 (Fig. 1d). The $\mathrm{pH}$ optimum of AtSOX was pH 6.5 (Fig. 1b). The enzyme activity was totally inhibited by $10 \mathrm{mM}$ zinc sulphate in the assay conditions. The relative SOX activity was $4 \%$ with $1 \mathrm{mM}$ zinc sulphate. The inhibition of zinc sulphate was confirmed with HVA-peroxidase coupled assay (Additional file 3). The other analysed compounds did not inhibit AtSOX activity, or had only minor effect on it, as residual activity was more than $90 \%$ in the presence of the analysed compound. For example the AtSOX retained $92 \%$ of its activity in $10 \mathrm{mM}$ of potassium iodide solution and denaturant SDS did not inhibit enzyme activity. The flavoenzymatic nature of AtSOX was determined by spectral analyses using UV-vis and fluorescence spectrophotometry. The absorption spectra were recorded before and after thermal denaturation of AtSOX. The flavin cofactor was released by denaturation and detected in solution (Fig. 2). The UV-vis spectrum of AtSOX showed the characteristic peaks of flavoproteins with absorbance maxima at 275, 365 and $445 \mathrm{~nm}$ with a shoulder at $475 \mathrm{~nm}$. AtSOX fluorescence emission spectrum had a peak at $525 \mathrm{~nm}$ when excited at $450 \mathrm{~nm}$, which is characteristic for flavins.

The purified AtSOX was subjected to Edman degradation, and trypsin digestion to perform peptide mass fingerprinting (PMF), and to identify the protein. The PMF gave six peptides made of more than six amino acids (Fig. 3). Mining the available genome of A. tubingensis [39] with the sequences of the identified peptides allowed the identification of a single SOX-coding gene on scaffold 13. This gene coded for a $41.8 \mathrm{kDa}$ secreted protein with a predicted $\mathrm{N}$-terminus, after removal of the signal peptide, SSIPQ. This protein contained four of the six peptides identified from AtSOX, and the other two peptides were present but carry either an amino acid insertion or deletion. Due to the high sequence similarity with secreted SOX from A. niger (UniProtKB: A2QUK3), the strain was re-identified at the Identification Services CBS (Utrecht, the Netherlands). The identification results confirmed that the used VTT strain D85248 was $A$. tubingensis. 

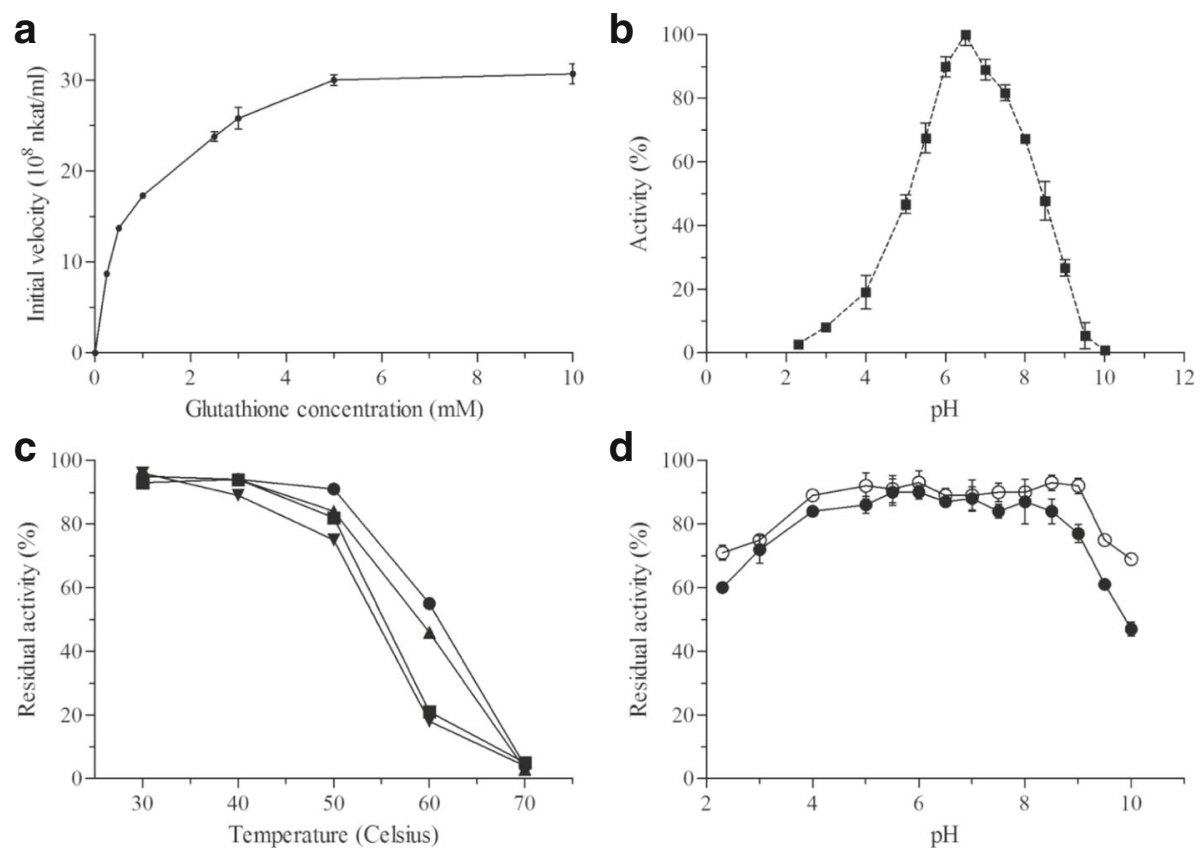

Fig. 1 Kinetics, pH optimum and thermal and pH stability of AtSOX. AtSOX activity on GSH (0.25-10 mM) measured by the oxygen consumption assay (a). AtSOX activity was measured with the oxygen consumption assay on GSH (3 mM) at room temperature to determine the pH optimum (b) and temperature stability after $1 \mathrm{~h}$ (filled circle), $2 \mathrm{~h}$ (filled triangle), $15.5 \mathrm{~h}$ (filled square) and $20 \mathrm{~h}$ (filled inverted triangle) of incubation at different temperatures $\left(30-70^{\circ} \mathrm{C}\right)(\mathbf{c})$. $\mathrm{pH}$ stability of AtSOX as analysed by oxygen consumption measurements, when incubated within a pH range from 2.3 to 10 for 1 (empty circles) or $20 \mathrm{~h}$ (filled circles) (d). Each curve represents average of two replicates (standard deviation < 10\%)

\section{Oxidation of peptides and proteins with AtSOX}

The ability of AtSOX to oxidise peptide-bound cysteine was tested with reduced model peptides and protein namely GSH, bikunin, insulin B chain, gliotoxin, holomycin and RNase A as substrates. Reaction products were analysed by MALDI-TOF MS and NMR spectroscopy. The MALDI-TOF MS analysis of the reaction mixtures showed a dimer (613 Da) formation with GSH after overnight enzymatic treatment whereas only a peak

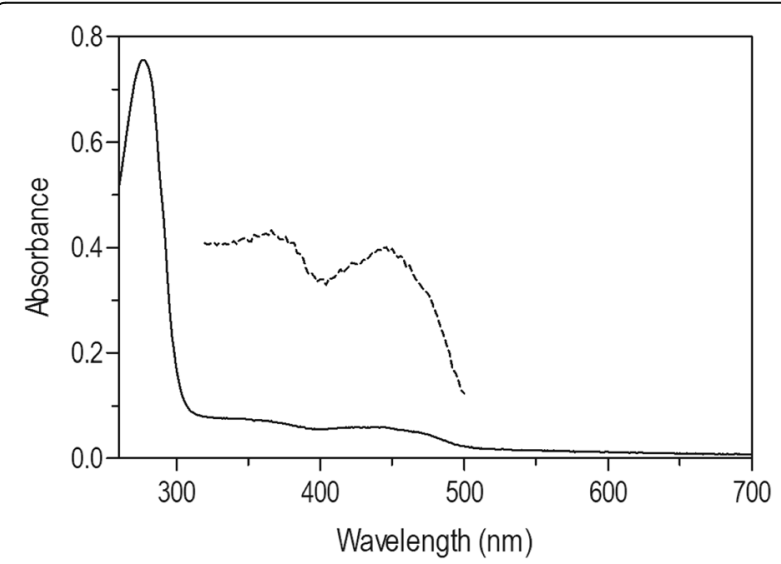

Fig. 2 UV-visible spectrum of AtSOX enzyme. The absorbance spectra of AtSOX (continuous line) and of the released FAD (values 10X, dashed line) are shown correspond to the monomer (308 Da) was detected in the mass spectrum of the untreated substrate. The enzymatic disulphide bond formation between GSH peptides was observed also with the spectroscopic measurements at $250 \mathrm{~nm}$ (Additional file 4). No dimer formation was detected with bikunin (919 Da), insulin B chain (3496 Da) or RNaseA $(13,700 \mathrm{Da})$ as substrates by MALDI-TOF analysis. Other analysed small peptides - gliotoxin (326 Da) and holomycin (214 Da) - were not enzymatically oxidised as observed in the LC-MS analysis. Holomycin was auto-oxidised as oxidation was observed also with the denaturated AtSOX enzyme after 50 min incubation.

Oxidation of GSH and RNase A by AtSOX was also followed. AtSOX could oxidise only the tripeptide GSH, which was the shortest tested peptide. The final product formed in the reaction of AtSOX was analysed using NMR spectroscopy. Hereby, it was possible to follow the change in the cysteine oxidation state at atomic resolution. The oxidation was confirmed by following the oxygen consumption for 20 min after addition of AtSOX to the tripeptide L-GSH. The fresh GSH and enzymetreated sample were analysed with one dimensional ${ }^{1} \mathrm{H}$ NMR. The one dimensional ${ }^{1} \mathrm{H}$ spectra of GSH with and without AtSOX enzyme are shown in Fig. 4. Upon addition of AtSOX to GSH solution, the two degenerate protons bonded to $C_{\beta}$ of cysteine residue became nondegenerated due to the formation of covalent disulphide 


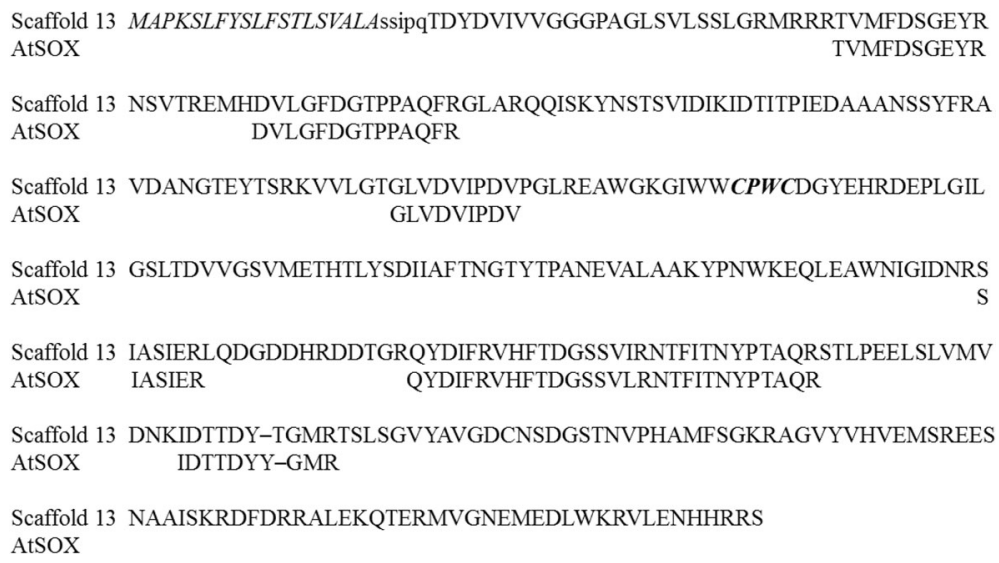

Fig. 3 The reconstructed AtSOX sequence. Alignment of the peptides obtained by tryptic digestion of AtSOX and the protein they identify on scaffold 13 of the genome of $A$. tubingensis [13]. The predicted signal sequence is in italic, the experimentally determined N-terminus of AtSOX is in lower case and the catalytic di-cysteine motif is bold in italic

bond. In addition, the two dimensional ${ }^{13} \mathrm{C}-\mathrm{HSQC}$ spectrum, exhibiting one-bond ${ }^{1} \mathrm{H}_{-}{ }^{13} \mathrm{C}$ connectivities (Fig. 5a) showed a significant change in the ${ }^{13} \mathrm{C}$ chemical shift of the Cys ${ }^{13} \mathrm{C}_{\beta}{ }_{-}{ }^{1} \mathrm{H}$ correlations as common for disulfide bond formation. This confirmed the fast dimerization of the GSH tripeptide through the disulfide bond upon addition of AtSOX. The control GSH substrate was checked once more 3 days after preparation with the gradient-enhanced ${ }^{13} \mathrm{C}$-HSQC spectrum to analyse auto-oxidation. The ${ }^{1} \mathrm{H},{ }^{13} \mathrm{C}$ cross peak, corresponding to the oxidised Cys $C_{\beta}$ form, started to appear which

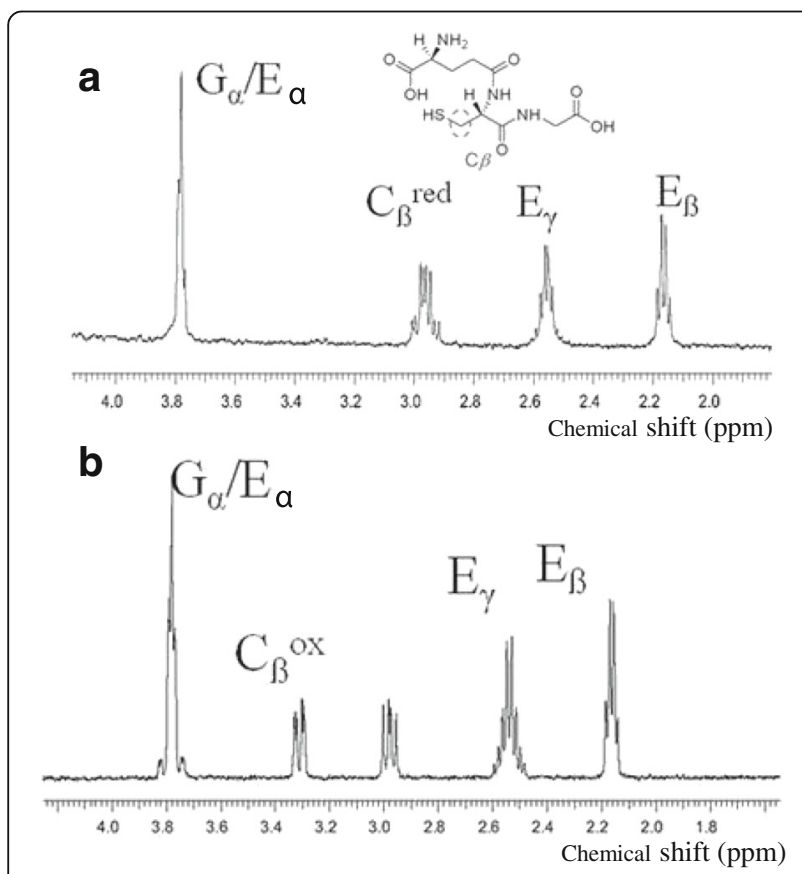

Fig. 4 One dimensional ${ }^{1} H$ NMR spectra of reduced GSH (a) and GSH after incubation in the presence of AtSOX enzyme (b). The chemical structure of reduced GSH is shown as inset in (a) refers to dimerization (Fig. 5b). The dimerization of GSH occurred also without the SOX enzyme, although at a much slower rate. Measurement of the pure GSH sample 3 days after preparation showed an evidence of both monomeric and dimeric conformations in a ratio of about 5:1.

\section{SOX-coding genes in fungal genomes and phylogenetics}

Aspergilli are known for their expanded secondary metabolism in comparison to yeasts [38], while fungi in general are known for their metabolic gene clusters, which are involved in, for example, synthesis of secondary metabolites [43] and catabolism of nutrients [37]. In order to suggest physiological roles for fungal secreted SOXs, fungal genomes were analysed. In brief, 33 fungal genomes were searched with custom $\mathrm{R}$ scripts for short genomic regions that would contain a SOX-coding genes and type of fungal secondary metabolism genes i.e. nonribosomal peptide synthetases (NRPS), polyketide synthases (PKS) and associated genes, i.e. cytochrome $\mathrm{P} 450$ monooxygenases (P450), and/or Zn2Cys6 transcription factors (Zn2).

No genomic regions containing genes coding for PKS and SOX could be found, instead ten regions with SOX, NRPS and P450 or Zn2 coding genes were identified (Fig. 6). Two of these regions were the gliotoxin synthesis cluster of A. fumigatus [44] and the candidate gliotoxin cluster of Trichoderma reesei [45]. In addition, the A. tubingensis candidate gliotoxin cluster was detected (Fig. 6a). Based on protein clustering of SOX enzymes [38] the SOX enzymes found in the chromosomal gene clusters were divided in two groups: SOX enzymes of candidate gliotoxin gene clusters (Fig. 6a) and SOX enzyme of candidate secondary metabolism gene clusters (Fig. 6b).

AtSOX sequence retrieved from Aspergillus tubingensis genome project was aligned with selected 24 SOX and thioredoxin reductase sequences from IPR000103 

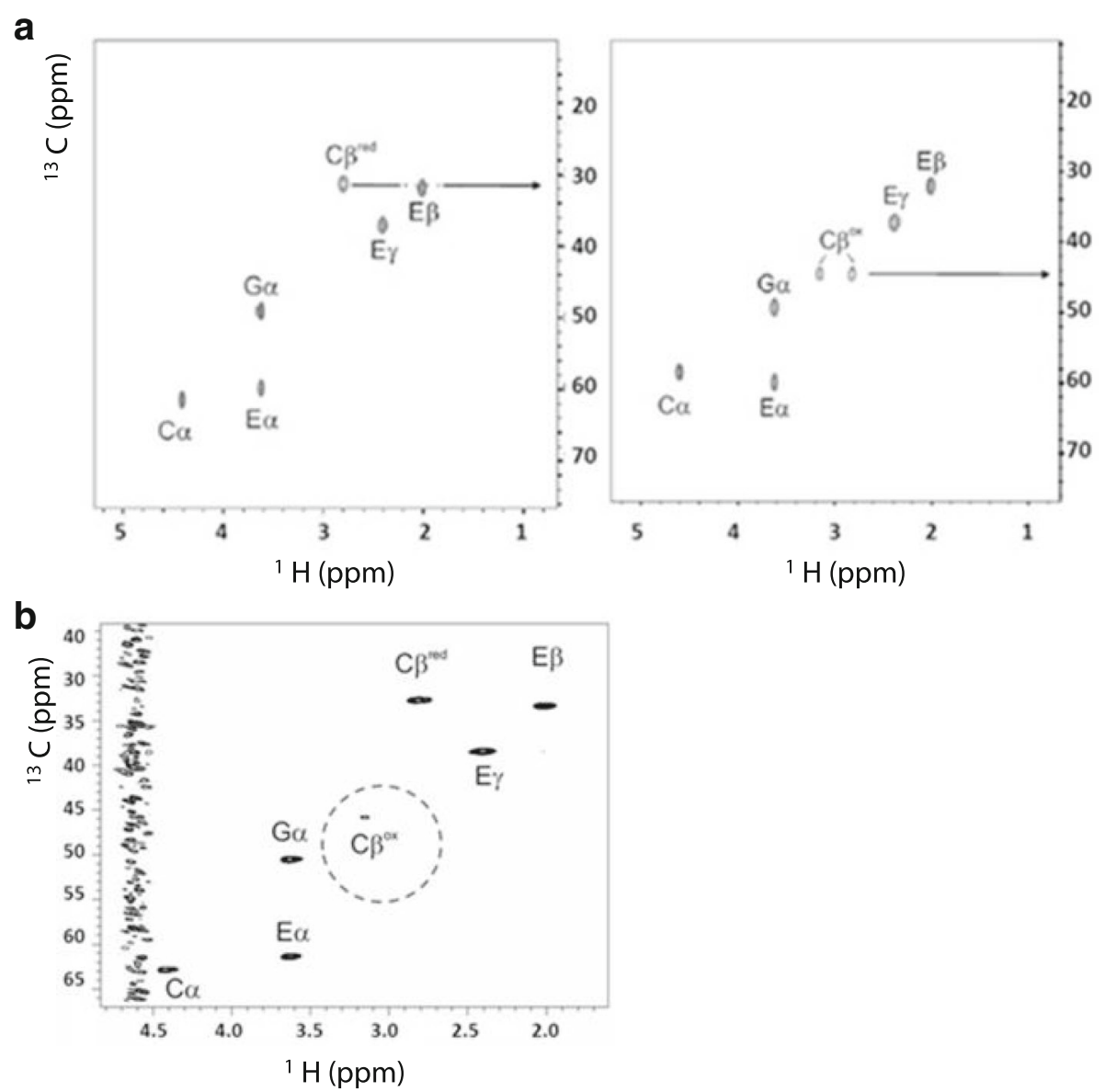

Fig. 5 Oxidation of GSH by AtSOX as analysed by two-dimensional heteronuclear NMR spectroscopy $\left({ }^{13} \mathrm{C}-\mathrm{HSQC}\right.$ spectra showing one-bond ${ }^{1} \mathrm{H}-{ }^{13} \mathrm{C}$ connectivities). The reduced substrate is shown on the left side as control and the enzyme-treated sample on the right side. The assignment of the tripeptide is indicated on the top of the cross-peaks. Arrows emphasize the chemical shift change in the $C_{\beta}$ correlation of cysteine in the two conformations i.e. in the cross-linked and open form (a). The gradient selected ${ }^{13} \mathrm{C}-\mathrm{HSQC}$ spectrum of the substrate control to evaluate auto-oxidation three days after the preparation (b)

InterPro family, and the phylogenetic tree was constructed based on the alignment (Fig. 7). The C-X-X-Cmotif was found from the majority of the aligned sequences (Additional file 7). It was observed from the phylogenetic tree that Aspergillus SOXs were evolutionary closely related. Oxidoreductases with activity on nonribosomal peptides, namely GliT, DepH and HlmI, were also closely related to AtSOX.

\section{Discussion}

Various fungi and bacteria have been shown to secrete enzymes with a sulfhydryl oxidase activity. In this work, we focused on a secreted SOX from the fungus A. tubingensis and report the biochemical characterization of the secreted sulfhydryl oxidase AtSOX. A. tubingensis was previously identified as a natural SOX-producing strain [28]. In addition, we investigated the possible physiological role of SOX enzymes by bioinformatics means, as no clear role has yet been established for secreted fungal SOXs thus far. The SOX produced by A. tubingensis showed characteristics common to other secreted fungal SOXs. The small thiol group containing tripeptide GSH was a preferred substrate of AtSOX as earlier also reported for other SOXs of fungal origin [1, 3, 6, 19, 34]. The enzyme had a non-covalently bound FAD as a cofactor, which could be released by thermal denaturation of the protein, and the UV-vis spectrum of AtSOX showed the characteristic peaks of flavoproteins [3, 19, 34]. Inhibition studies with different salts showed that AtSOX activity was inhibited in the presence of zinc sulphate. Inhibition by zinc sulphate was observed also with secreted fungal SOXs from A.oryzae and Penicillium [3, 19, 34]. The catalytic center of SOX contains two reactive cysteine residues forming a $\mathrm{C}$-X-X-C-motif $[46,47]$. The cysteine residues are able to chelate divalent metal ions such as zinc, and the enzyme inhibition might be due to interact of zinc and cysteine as discussed in [23]. AtSOX showed 

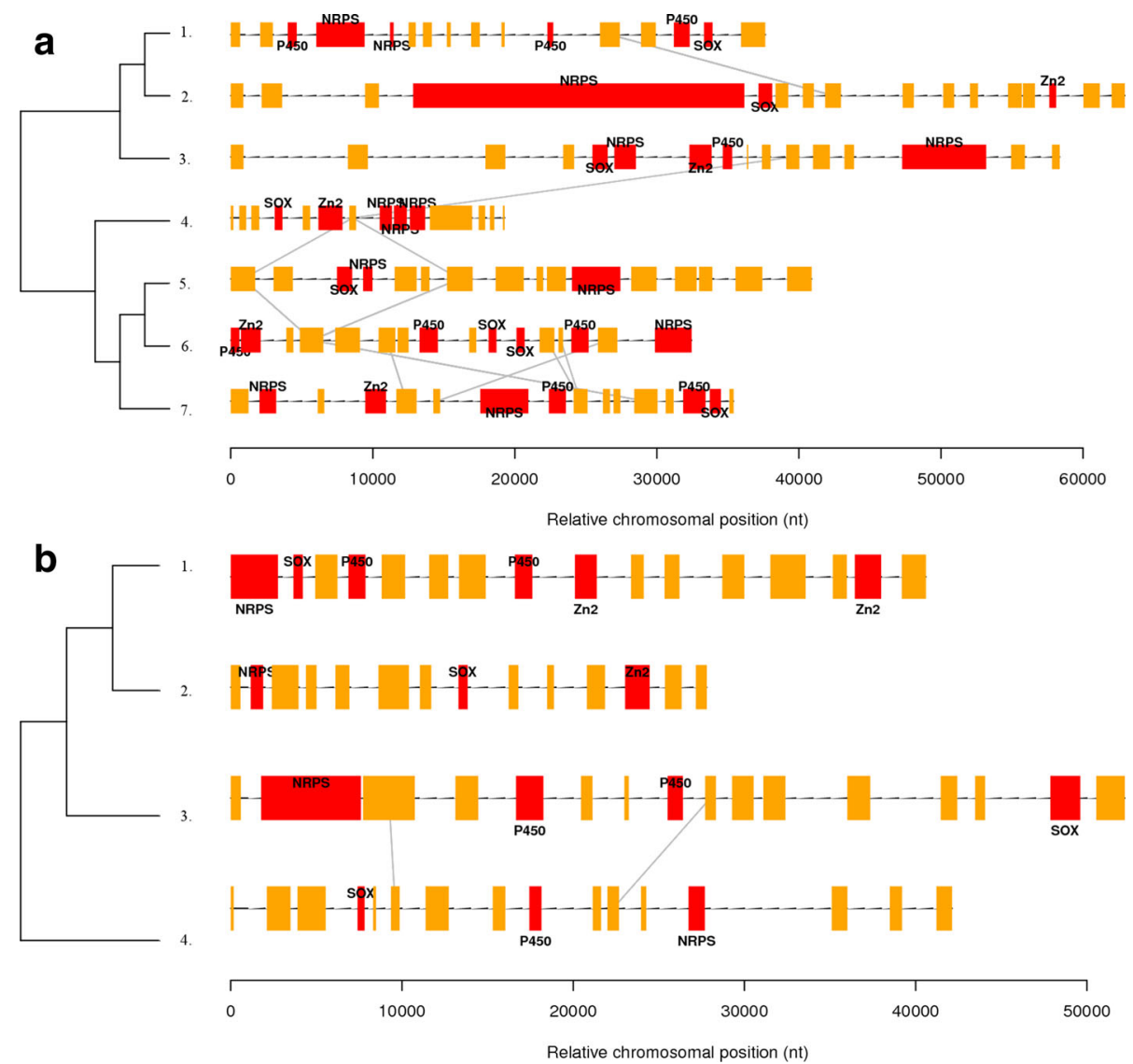

Fig. 6 Candidate secondary metabolism clusters with SOX enzymes on fungal chromosomes. On the left an approximate phylogenetic tree of the species compiled from literature [36, 37]. On the right a stretch of a scaffold from each species containing the cluster and neighbouring genes. Genes are shown as boxes on the scaffold stretch. NRPS, PKS, P450 and Zn2 are indicated when present. Grey lines connect genes with identical protein domains on adjacent scaffolds (excluding NRPS, PKS, P450, Zn2 and SOX-coding genes) in order to reveal syntenies. Panel a. shows the gliotoxin clusters, while panel (b). shows other clusters. The strains in panel (a). are (1.) Trichoderma reesei, (2.) Fusarium graminearum, (3.) Chaetomium globusum, (4.) Phaeosphaeria nodorum, (5.) A. tubingensis, (6.) A. oryzae and (7.) A. fumigatus. The stains shown in panel (b). are (1.) Fusarium graminearum, (2.) Magnaporthe grisea, (3) A. fumigatus and (4.) Phanerochaete chrysosporium. Additional details are given in the Additional files 5 and 6

good thermal stability up to $50{ }^{\circ} \mathrm{C}$ retaining $75 \%$ of its activity for $20 \mathrm{~h}$. The thermostability of other known fungal SOX, AoSOX2 from A. oryzae, is on the same range [19].

The small thiol-containing molecules, like reduced GSH, cystein and DTT, are typical substrates for secreted fungal SOXs $[3,11,19,34]$. The protein-bound thiols groups, particularly on reduced RNase A, have also been reported to be substrates for microbial SOXs from A. niger and Penicillium $[1,3]$. Later analysis have shown that reported oxidation of RNaseA was spontaneous and non-enzymatic [23]. Our results also indicated that protein-bound cysteines in RNaseA (protein size $13.7 \mathrm{kDa}$ ) were not oxidised by AtSOX, but instead among the analysed compounds the tripeptide GSH was the preferred substrate. It was confirmed by NMR spectroscopy studies that the oxidation reaction of GSH was enzyme-catalysed. GSH was a good substrate for AtSOX based on the oxygen consumption analysis. AtSOX preferred GSH $\left(\mathrm{K}_{\mathrm{m}} 0.8 \mathrm{mM}\right)$ as a substrate over DTT, L- cysteine and D-cysteine. Other characterised SOXs from A. oryzae preferred cysteine as a substrate over GSH. AoSOX1 had smaller $K_{m}$ for L-cystein $(0.9 \mathrm{mM})$ than for GSH $(2.78 \mathrm{mM})$, and AoSOX2 preferred D-cystein $\left(K_{\mathrm{m}} 1.55 \mathrm{mM}\right)$ over GSH $\left(\mathrm{K}_{\mathrm{m}} 3.7 \mathrm{mM}\right)$ [19, 34]. The sulfhydryl groups in the longer peptides and proteinbound sulfhydryl groups were not oxidised suggesting preference for small substrates, which could have a better access into the active site of the enzyme. The QSOXs from an animal source, for instance bovine SOX, are known to oxidase protein-bound thiol groups and contribute in the oxidative protein folding [20], however secreted fungal SOXs are shown to have different substrate specificity and probably also a different physiological role. In this work, based on the genome analyses was suggested that secreted fungal SOXs might have role in the maturation of nonribosomal peptides.

It is not common for secondary metabolites of fungal and bacterial origin to contain disulphide bonds. 


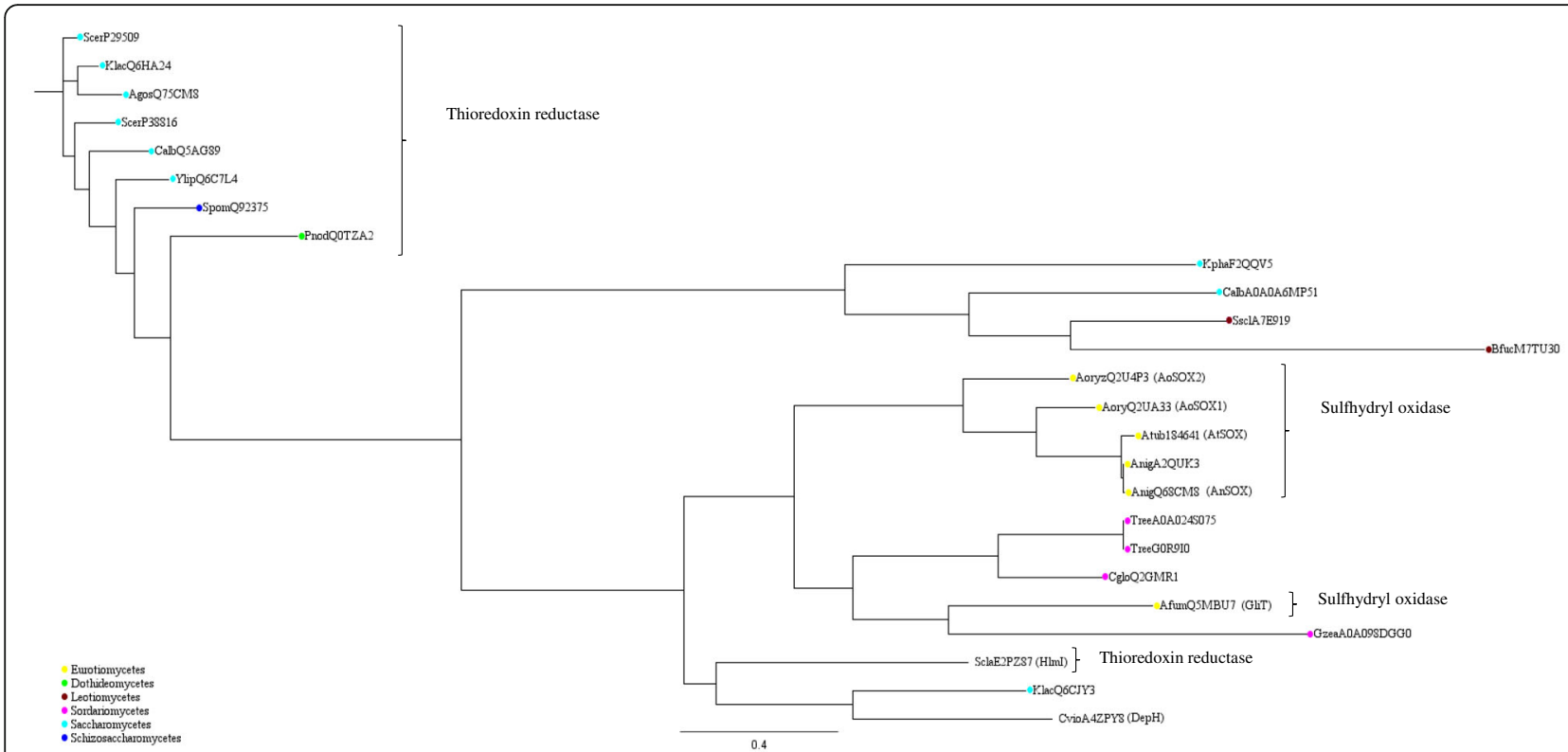

Fig. 7 Phylogenetic tree including AtSOX. The phylogenetic tree of selected 25 SOX and thioredoxin reductase sequences from the IPR000103 protein family pyridine nucleotide-disulphide oxidoreductase, class-II (InterPro IPR000103). The sequences: AfumQ5MBU7, GliT SOX from Aspergillus fumigatus (UniProtKB: Q5MBU7); AgosQ75CM8, protein from Ashbya gossypii (UniProtKB: Q75CM8); AnigA2QUK3, SOX from Aspergillus niger (UniProtKB: A2QUK3); AnigQ68CM8, AnSOX from Aspergillus niger (UniProtKB: Q68CM8); AoryQ2UA33, AoSOX1 from Aspergillus oryzae (UniProtKB: Q2UA33); AoryQ2U4P3, AoSOX2 from Aspergillus oryzae (UniProtKB: Q2U4P3); Atub184641, AtSOX from Aspergillus tubingensis (JGI code 184641); BfucM7TU30, protein from Botryotinia fuckeliana (UniProtKB: M7TU30); CalbA0A0A6MP51, protein from Candida albicans (UniProtKB: A0A0A6MP51); CalbQ5AG89, protein from Candida albicans (UniProtKB: Q5AG89); CgloQ2GMR1, protein from Chaetomium globosum (UniProtKB: Q2GMR1); CvioA4ZPY8, DepH protein from Chromobacterium violaceum (UniProtKB: A4ZPY8); GzeaA0A098DGG0, protein from Gibberella zeae (UniProtKB: A0A098DGG0); KlacQ6CJY3, protein from Kluyveromyces lactis (UniProtKB: Q6CJY3); KlacQ6HA24, protein from Kluyveromyces lactis (UniProtKB: Q6HA24); KphaF2QQV5, protein from Komagataella phaffii (UniProtKB: F2QQV5); PnodQ0TZA2, protein from Phaeosphaeria nodorum (UniProtKB: Q0TZA2); ScerP29509, protein from Saccharomyces cerevisiae (UniProtKB: P29509); ScerP38816, protein from Saccharomyces cerevisiae (UniProtKB: P38816); SclaE2PZ87, HIml protein from Streptomyces clavuligerus (UniProtKB: E2PZ87); SpomQ92375, protein from Schizosaccharomyces pombe (UniProtKB: Q92375); SsclA7E919, protein from Sclerotinia sclerotiorum (UniProtKB: A7E919); TreeA0A024S075, protein from Trichoderma reesei (UniProtKB: A0A024S075); TreeG0R910, protein from Trichoderma reesei (UniProtKB: G0R910); YlipQ6C7L4, protein from Yarrowia lipolytica (UniProtKB: Q6C7L4)

Maturation mechanisms of these low-molecular mass metabolites are still unclear [48]. Thiol oxidising enzymes, oxidoreductases GliT, DepH and HlmI, have been reported to be involved in the maturation of gliotoxin from A. fumigatus, of the anticancer peptide romidepsin (FK228) in Chromobacterium violaceum No. 968, and of the antimicrobial compound holomycin in Streptomyces clavuligerus, respectively [48, 49]. A FAD-dependent SOX enzyme, GliT (dimeric $\sim 60 \mathrm{kDa}$ ), belongs to the $A$. fumigatus gliotoxin chromosomal gene cluster, and it has been shown to form the atypical intramolecular disulfide bond responsible for toxicity of gliotoxin [44, 50]. GliT utilizes molecular oxygen as terminal electron acceptor with concomitant formation of hydrogen peroxide [51]. Similarly, a dimeric FAD-dependent pyridine nucleotide-disulfide oxidoreductase DepH (dimeric $\sim 70 \mathrm{kDa}$; UniProtKB: A4ZPY8) has been found responsible for the introduction of a disulfide bond in the FDA-approved anticancer peptide FK228 from the Gram-negative C. violaceum [27]. Functionally homologous to GliT and $\mathrm{DepH}$, a dimeric FAD-dependent thiol oxidising enzyme HlmI has been proven to be involved in the maturation of holomycin from S. clavuligerus [49]. DepH, GliT and HlmI shared common features with secreted fungal SOXs such as AoSOX1 and AoSOX2 (UniProtKB: Q2UA33, Q2U4P3), characterized by our group, and the reconstructed AtSOX sequence of this work (Fig. 3). They all carried sequence features of FAD-dependent pyridine nucleotide-disulfide oxidoreductase (InterPro: IPR013027 and the subclass II InterPro: IPR000103 used in this genome analysis study). AoSOX1 and AoSOX2 were proven FAD-dependent, dimeric and able to oxidise small thiol-containing peptide molecules such as GSH, cysteine and DTT. The reconstructed sequence of AtSOX shared 22-96\% identity to other known secreted Aspergillus SOXs and oxidoreductases DepH, GliT and HlmI (Table 1). The flavoenzymes GliT, DepH and HlmI have a common reaction mechanism, although they have differences in substrate specificity [48]. The substrate binding clefts of GliT, DepH and HlmI enzymes are different but they all oxidise small molecules and introduce the disulfide bond to the corresponding secondary metabolites of fungi or bacteria [48]. 
Table 1 Biochemical characteristics of selected secreted flavin-dependent sulfhydryl oxidases and the enzymes DepH, GliT and HIml reported to be involved in the secondary metabolism

\begin{tabular}{|c|c|c|c|c|c|c|c|}
\hline \multirow[b]{2}{*}{ Enzyme } & \multicolumn{5}{|c|}{ Biochemical properties } & \multirow[b]{2}{*}{ Identity (\%) to AtSOX } & \multirow[b]{2}{*}{ Reference } \\
\hline & MW (kDa) & pH optimum & pH stability & Temperature stability & Cofactor, non covalent & & \\
\hline AtSOX & 55 & 6.5 & $\begin{array}{l}>80 \% \text { activity after } \\
20 \mathrm{~h} \text { at } \mathrm{pH} 4-8.5\end{array}$ & $\begin{array}{l}>85 \% \text { activity after } \\
20 \text { h at } 40{ }^{\circ} \mathrm{C}\end{array}$ & FAD & 100 & This study \\
\hline AnSOX & 53 (dimer) & 5.5 & n.a. & n.a. & $\mathrm{FAD}$ & 96.0 & [1] \\
\hline AoSOX1 & 45 (dimer) & 8.0 & $\begin{array}{l}>80 \% \text { activity after } \\
24 \mathrm{~h} \text { at } \mathrm{pH} 5-8.5\end{array}$ & $\begin{array}{l}>70 \% \text { activity after } \\
24 \mathrm{~h} \text { at } 40{ }^{\circ} \mathrm{C}\end{array}$ & $\mathrm{FAD}$ & 64.6 & {$[34]$} \\
\hline AoSOX2 & 45 (dimer) & $7.5-8.0$ & $\begin{array}{l}>80 \% \text { activity after } \\
24 \mathrm{~h} \text { at } \mathrm{pH} 5-8\end{array}$ & $\begin{array}{l}>65 \% \text { activity after } \\
1 \mathrm{~h} \text { at } 60{ }^{\circ} \mathrm{C}\end{array}$ & $\mathrm{FAD}$ & 46.5 & [19] \\
\hline DepH & 34.4 (dimer) & 7 (assay) & n.a. & n.a. & FAD & 22.0 & {$[27]$} \\
\hline GliT & 30 (dimer) & 6.5 (assay) & n.a. & n.a. & $\mathrm{FAD}$ & 24.5 & {$[44,51]$} \\
\hline $\mathrm{HIml}$ & 39 (dimer) & 6.5 (assay) & n.a. & n.a. & FAD & 22.3 & [49] \\
\hline
\end{tabular}

Abbreviations: AtSOX secreted SOX from Aspergillus tubingensis, AnSOX secreted SOX from Aspergillus niger (UniProtKB: Q68CM8), AoSOX secreted SOX from Aspergillus oryzae (AoSOX1 UniProtKB: Q2UA33, AoSOX2 UniProtKB: Q2U4P3), DepH enzyme from Chromobacterium violaceum (UniProtKB: A4ZPY8), GliT enzyme from Aspergillus fumigatus (UniProtKB: Q5MBU7), HIml enzyme from Streptomyces clavuligerus (UniProtKB: E2PZ87), MW molecular weight of the subunit, SOX sulfhydryl oxidase, n.a. not available

Most of the secondary metabolites are derivatives from nonribosomal peptides and polyketides, the synthesis of which is catalysed by the multidomain enzymes belonging to NRPSs and PKSs [52]. Nonribosomal peptides are a class of molecules characterised by a vast structural and functional diversity, e.g. they can have linear, cyclic, or branched structures and activities ranging from antibiotic to metal-binding, from immunosuppressive to toxic and cytostatic [53]. Most of the fungal gene clusters for the secondary metabolite biosynthesis are silent under laboratory conditions [52]. The results (Fig. 6) indicated that SOX-coding genes are associated with NRPS, but not PKS, clusters and thus SOXs are possibly to act as accessory enzymes in the production of nonribosomal peptides. Thus, based on the genome studies, a connection between nonribosomal peptides and SOXs was suggested, since SOX and the nonribosomal peptide synthetase coding genes were found in the same clusters in the analysed fungal genomes. However, in vitro enzymatic oxidation of selected nonribosomal peptides (i.e. gliotoxin and holomycin) was not detected. This could be due to a challenging location of sulfhydryl groups in the circular structure of the peptides, and hence poor availability. Moreover flavoenzymes GliT, DepH and HlmI all have different substrate specificity. The cellular localisation, ability to oxidise small thiol-containing peptides, and genome comparison of secreted SOXs support the idea that fungal secreted SOXs are involved in the biosynthesis of disulfide-containing secondary metabolites, such as nonribosomal peptides. Their role could thus be in the maturation of peptides produced nonribosomally.

\section{Conclusions}

This paper describes the characterization of a flavindependent secreted fungal SOX from Aspergillus tubingensis (AtSOX). AtSOX was shown to have good thermal stability and the enzyme retained high activity in the broad $\mathrm{pH}$ range. The enzyme preferred GSH as a substrate over the tested small-thiol containing molecules (reduced cysteine and DTT). The enzyme activity was drastically reduced in the presence of zinc sulphate. The enzymatic oxidation of the tripeptide GSH and formation of a disulphide bond was verified by nuclear magnetic resonance spectroscopy. AtSOX was evolutionary closely related to other Aspergillus SOXs and the oxidoreductases GliT, HlmI and DepH of fungal and bacterial origin, whereas fungal thioreductases were evolutionary more distant. Based on the location near to NRPSs encoding genes, SOXs could be involved in the secondary metabolism and act as an accessory enzyme in the production of nonribosomal peptides.

\section{Additional files}

Additional file 1: Purification of AtSOX as analysed by SDS-PAGE. Molecular weight (MW) standards are shown in lanes 1 and 9. The sample from initial crude cell-free medium is shown in lane 2. As a first purification step was used anion exchange chromatography with a $\mathrm{Q}$ Sepharose column. In lane 3 are the unbound proteins, and in the lanes 4-6 bound and then eluted proteins, from Q Sepharose column. Lane 6: AtSOX containing fractions selected for further purifications steps. In the lanes marked 7 and 8 are shown fractions obtained from the last purification step using anion exchange chromatography with Resource Q column (analysed in a separate SDS-PAGE gel with MW standards in lane 9). (PPTX 137 kb)

Additional file 2: AtSOX activity measured by oxygen consumption assay using $3 \mathrm{mM}$ reduced GSH as a substrate (continuous line). The reaction occurred at the enzymatic rate (the linear area ca. 0.5 - $3.5 \mathrm{~min}$ ). The amount of dissolved oxygen in the reduced GSH solution prior addition of enzyme is shown with a dashed line. The triplicate measurements were done. (PPTX $6691 \mathrm{~kb}$ )

Additional file 3: AtSOX activity measured by HVA-peroxidase coupled assay using reduced GSH (5 mM) as a substrate according to [33]. The enzyme reaction is at the enzymatic rate (linear area ca. $0-150 \mathrm{~s}$ ). The 
production of the fluorescent HVA dimer was followed at excitation wavelength $320 \mathrm{~nm}$ and emission wavelength $420 \mathrm{~nm}$. The reduced AtSOX activity with the inhibitor zinc sulphate $(10 \mathrm{mM})$ is also shown (dashed line). The triplicate measurements were done. (PPTX $121 \mathrm{~kb}$ )

Additional file 4: Absorbance spectra (ca. $10 \mathrm{~min}$ ) of $5 \mathrm{mM}$ reduced GSH (a.) and $5 \mathrm{mM}$ reduced GSH with AtSOX (b.). Arrow indicates the direction of increased UV adsorption due to enzymatic oxidation of the substrate. (PPTX $395 \mathrm{~kb}$ )

Additional file 5: Details to Fig. 6 Candidate secondary metabolism clusters with SOX enzymes on fungal chromosomes. On the left an approximate phylogenetic tree of the species compiled from literature $[54,55]$. On the right a stretch of a scaffold from each species containing the cluster and neighbouring genes. Genes are shown as boxes on the scaffold stretch. NRPS, PKS, P450 and Zn2 are indicated when present. Grey lines connect genes with identical protein domains on adjacent scaffolds (excluding NRPS, PKS, P450, Zn2 and SOX genes) in order to reveal syntenies. Codes above the gene boxes are their identifiers and below them the Interpro protein domain identifiers found in the genes. Panel a. shows the gliotoxin clusters, while panel b. shows other clusters. The strains shown in panel a. are Trichoderma reesei, Fusarium graminearum, Chaetomium globusum, Phaeosphaeria nodorum, A. tubingensis, A. oryzae and A. fumigatus. The stains shown in panel b. are F. graminearum, Magnaporthe grisea, A. fumigatus and Phanerochaete chrysosporium. (PNG $335 \mathrm{~kb}$ )

Additional file 6: For each chromosomal cluster the table shows accession numbers for genes (Accession), scaffold identifier (Scaffold), start and end on the scaffold, direction of the gene (Direction) and Interpro protein domain identifiers found in the genes (Interpro), as details for Additional file 5. (XLSX $20 \mathrm{~kb}$ )

Additional file 7: Part of the alignment of 25 sequences from the same protein family (InterPro IPRO00103). On the first line is shown AtSOX retrieved from $A$. tubingensis genome. The $C-X-X-C$ motifs are marked with a box. The sequences: AtSOX, secreted SOX from A. tubingensis; AnSOX, secreted SOX from A. niger; AoSOX, secreted SOX from A. oryzae; DepH, enzyme from C. violaceum; GliT, enzyme from A. fumigatus; HIml, enzyme from S. clavuligerus. The other abbreviations are shown in the legend of Fig. 7. (PPTX 95 kb)

\section{Abbreviations \\ ${ }^{13} \mathrm{C}-\mathrm{HSQC}:{ }^{13} \mathrm{C}$ heteronuclear single quantum correlation (spectroscopy); AtSOX: Secreted SOX enzyme from Aspergillus tubingensis; CHCA: a-cyano-4- hydroxycinnamic acid; DTNB: 5,5-dithio-bis(2-nitrobenzoic acid), Ellman's reagent; DTT: Dithiothreitol; EDTA: Ethylenediaminetetraacetic acid; FAD: Flavin adenine dinucleotide; GSH: The reduced glutathione; HVA: Homovanillic acid; MALDI-TOF MS: Matrix-assisted laser desorption- ionization time of flight mass spectrometry; NMR: Nuclear magnetic resonance (spectroscopy); NRPS: Nonribosomal peptide synthetases; PKS: Polyketide synthases; PMF: Peptide mass fingerprinting; PNDR: Pyridine nucleotide-disulfide oxidoreductase; QSOX: The quiescin-sulfhydryl oxidase; Q-TOF: Quadruple time-of-flight: RNase A: Ribonuclease A: SDS: Sodium dodecyl sulphate; SEC: Size-exclusion chromatography; SOX: Sulfhydryl oxidase; TOCSY: Homonuclear total correlation spectroscopy; UPLC: Ultra performance liquid chromatography}

\section{Acknowledgements}

Dr. Peter Würtz is acknowledged for NMR spectroscopy work (Finnish National Biological NMR center, Institute of Biotechnology, University of Helsinki, Finland). Docent Nisse Kalkkinen is acknowledged for Edman degradation (Institute of Biotechnology, University of Helsinki, Finland). Dr. Elisabeth Heine (DWI, Deutsches Wolforshunginstitut, Aachen, Germany) is thanked for providing Insulin B chain for the study. Dr. Heli Nygren is thanked for the guidance in the LC-MS analysis. In addition Outi Liehunen and Riitta Isoniemi are thanked for the technical assistance relating to the purification of the enzyme. Päivi Matikainen and Gunilla Rönnholm (Institute of Biotechnology, University of Helsinki, Finland) are thanked for the technical assistance related to mass spectrometry.

\section{Funding}

The research was conducted in the Academy of Finland funded project 'Enzymatic crosslinking of food proteins: impact of food protein folding on the mode of action of crosslinking enzymes' (no: 110,965), the Finnish
Funding Agency for Technology and Innovation (Tekes) funded project 'Tailored nanostabilizers for biocomponent interfaces' (no: VTT-R-06743-08) and FP6 funded project 'High performance industrial protein matrices' (no: NMP-3-CT-2003-505,790). The work of Dr. Mikko Arvas was supported by Academy Postdoctoral Researcher's fellowship (no. 127715). Dr. Greta Faccio was funded by TYROMAT, a project within the Empa Postdocs programme that is co-funded by the FP7: People Marie-Curie action COFUND. The financiers had no role in the design of the study, collection, analysis and interpretation of data, or in writing the manuscript.

\section{Availability of data and materials}

The datasets used and/or analysed during the current study are available from the corresponding author on reasonable request. The datasets concerning the phylogenetic tree generated during the current study are available in the TreeBASE repository (https://treebase.org/treebase-web/search/study/ summary.html?id=21339).

\section{Authors' contributions}

ON carried out the experimental work and drafted the manuscript. MA carried out the genome mining study and assisted in writing the manuscript. KK and M-LM designed the research and participated in writing the manuscript.GF participated in the design of the study and helped to draft and write the manuscript. PP participated in the design of NMR studies. JB participated in the design and coordination of the study. All authors read and approved the final manuscript.

\section{Ethics approval and consent to participate}

Not applicable.

\section{Consent for publication}

Not applicable.

\section{Competing interests}

The authors declare that they have no competing interests.

\section{Publisher's Note}

Springer Nature remains neutral with regard to jurisdictional claims in published maps and institutional affiliations.

\section{Author details}

${ }^{1}$ VTT Technical Research Centre of Finland, Ltd., P.O. Box 1000, Fl-02044 Espoo, Finland. ${ }^{2}$ Independent scientist, St. Gallen, CH, Switzerland. ${ }^{3}$ Institute of Biotechnology, University of Helsinki, P.O. Box 65, Fl-00014 Helsinki, Finland. ${ }^{4}$ Department of Biological and Environmental Sciences, Nanoscience Center, University of Jyväskylä, P.O. Box 35, Fl-40014 Jyväskylä, Finland. ${ }^{5}$ Department of Chemistry, Nanoscience Center, University of Jyväskylä, P.O. Box 35, Fl-40014 Jyväskylä, Finland. ${ }^{6}$ Natural resources institute Finland (Luke), P.O. Box 2, Fl-00790 Helsinki, Finland. ${ }^{7}$ Department of Forest Products Technology, Bioproduct Chemistry, Aalto University, School of Chemical Technology, P.O. Box 16300, FI-00076 Espoo, Finland.

Received: 15 June 2017 Accepted: 20 November 2017 Published online: 08 December 2017

\section{References}

1. de la Motte RS, Wagner FW. Aspergillus niger Sulfhydryl oxidase. Biochem Int. 1987;26:7363-71. Available from: http://dx.doi.org/10.1021/bi00397a025

2. Gerber J, Mühlenhoff $U$, Hofhaus G, Lill R, Lisowsky T. Yeast Erv2p is the first Microsomal FAD-linked Sulfhydryl Oxidase of the Erv1p/Alrp protein family. J Biol Chem. 2001;276:23486-91. Available from: http://dx.doi.org/10.1074/ jbc.M100134200

3. Kusakabe $H$, Kuninaka A, Yoshino H. Purification and properties of a new enzyme, glutathione Oxidase from Penicillium sp. K-6-5. Agric Biol Chem. 1982;46:2057-67. Available from: http://dx.doi.org/10.1080/00021369.1982.10865382

4. Ostrowski MC, Kistler WS. Properties of a Flavoprotein Sulfhydryl Oxidase from rat seminal vesicle secretion. Biochemistry. 1980;19:2639-45. Available from: http://dx.doi.org/10.1021/bi00553a016

5. Kusakabe H, Midorikawa Y, Kuninaka A, Yoshino H. Distribution of extracellular oxygen related enzymes in Molds. Agric Biol Chem. 1983:47:1385-7. Available from: http://dx.doi.org/10.1080/00021369.1983.10857185 
6. Starnes RL, Katkocin DM, Miller CA, Strobel Jr. RJ. Microbial sulfhydryl oxidases [internet]. United States; 1986. Available from: http://www.freepatentsonline. com/4632905.pdf.

7. Fass D. The Erv family of sulfhydryl oxidases. Biochim Biophys Acta - Mol Cell Res. 2008;1783:557-66. Available from: http://dx.doi.org/10.1016/j. bbamcr.2007.11.009

8. Kodali VK, Thorpe C. Oxidative protein folding and the Quiescin-Sulfhydryl Oxidase family of Flavoproteins. Antioxid Redox Signal. 2010;13:1217-30. Available from: http://dx.doi.org/10.1089/ars.2010.3098

9. Sevier CS, Kaiser CA. Formation and transfer of disulphide bonds in living cells. Nat Rev Mol Cell Biol. 2002;3:836-47. Available from: http://dx.doi.org/ 10.1038/nrm954

10. Faccio G, Nivala O, Kruus K, Buchert J, Saloheimo M. Sulfhydryl oxidases: sources, properties, production and applications. Appl Microbiol Biotechnol. 2011;91:957-66. Available from: http://dx.doi.org/10.1007/s00253-011-3440-y

11. Vignaud C, Kaid N, Rakotozafy L, Davidou S, Nicolas J. Partial purification and characterization of Sulfhydryl Oxidase from Aspergillus niger. J Food Sci. 2002;67:2016-22. Available from: http://dx.doi.org/10.1111/j.1365-2621. 2002.tb09494.x

12. Hunter S, Jones P, Mitchell A, Apweiler R, Attwood TK, Bateman A, et al. InterPro in 2011: new developments in the family and domain prediction database. Nucleic Acids Res. 2012;40:D306-12. Available from: http://dx.doi. org/10.1093/nar/gkr948

13. de Vries RP, Riley R, Wiebenga A, Aguilar-Osorio G, Amillis S, Uchima CA, et al. Comparative genomics reveals high biological diversity and specific adaptations in the industrially and medically important fungal genus Aspergillus. Genome Biol. 2017;18:1-45. Available from: http://dx.doi.org/10. 1186/s13059-017-1151-0

14. Swaisgood HE. Process of removing the cooked flavor from milk. 1977 Available from: http://www.patents.com/us-4053644.html.

15. Faccio G, Flander L, Buchert J, Saloheimo M, Nordlund E. Sulfhydryl oxidase enhances the effects of ascorbic acid in wheat dough. J. Cereal Sci. Elsevier Ltd; 2012;55:37-43. Available from: http://dx.doi.org/10.1016/j.jcs.2011.10.002

16. Haarasilta S, Väisanen S, Scott D. Method for improving flour dough. 1989. Available from: https://www.google.com/patents/EP0321811B1?cl=en.

17. Kaufman SP, Fennema O. Evaluation of Sulfhydryl Oxidase as a Strengthening Agent for Wheat Flour Dough [Internet]. Cereal Chem. 64AD. p. 172-6. Available from: http://www.aaccnet.org/publications/cc/backissues/1987/ Documents/64_172.pdf

18. Koppelman SJ, van den Hout RHJA, Sleijster-Selis HE, Luijkx DMAM. Modification of allergens [Internet]. Netherlands; 2010. Available from: http://www.freepatentsonline.com/20100086568.pdf

19. Faccio G, Kruus K, Buchert J, Saloheimo M. Production and characterisation of AoSOX2 from Aspergillus oryzae, a novel flavin-dependent sulfhydryl oxidase with good $\mathrm{pH}$ and temperature stability. Appl Microbiol Biotechnol. 2011;90:941-9. Available from: http://dx.doi.org/10.1007/s00253-011-3129-2

20. Jaje J, Wolcott HN, Fadugba O, Cripps D, Yang AJ, Mather IH, et al. A FlavinDependent Sulfhydryl Oxidase in Bovine Milk. Biochemistry. 2007;46:1303140. Available from: http://dx.doi.org/10.1021/bi7016975

21. Ilani T, Alon A, Grossman I, Horowitz B, Kartvelishvily E, Cohen SR, et al. A secreted disulfide catalyst controls extracellular matrix composition and function. Science 2013;341:74-6. Available from: http://dx.doi.org/10.1126/science.1238279

22. Ang SK, Zhang M, Lodi T, Lu H. Mitochondrial thiol oxidase Erv1: both shuttle cysteine residues are required for its function with distinct roles. Biochem J. 2014;460:199-210. Available from: http://dx.doi.org/10.1042/BJ20131540

23. Janolino VG, Swaisgood HE. A comparison of sulfhydryl oxidases from bovine milk and from Aspergillus niger. Milchwissenschaft. 1992;47:143-6. Available from: http://eurekamag.com/research/006/937/006937840.php

24. Bin SK, Swaisgood HE, Horton HR. Requirement for a Sulfhydryl Group for Sulfhydryl Oxidase Activity. J Dairy Sci. 1986;69:2589-92. Available from: https://doi.org/10.3168/jds.S0022-0302(86)80705-6

25. Musard J-F, Sallot M, Dulieu P, Fraîchard A, Ordener C, Remy-Martin J-P, et al. Identification and expression of a new Sulfhydryl Oxidase SOx-3 during the cell cycle and the Estrus cycle in uterine cells. Biochem Biophys Res Commun. 2001;287:83-91. Available from: http://dx.doi.org/10.1006/bbrc.2001.5440

26. Tury A, Mairet-Coello G, Esnard-Fève A, Benayoun B, Risold P-Y, Griffond B, et al. Cell-specific localization of the sulphydryl oxidase QSOX in rat peripheral tissues. Cell Tissue Res. 2006:323:91-103. Available from: http://dx. doi.org/10.1007/s00441-005-0043-x

27. Wang C, Wesener SR, Zhang H, Cheng Y-Q. An FAD-Dependent Pyridine Nucleotide-Disulfide Oxidoreductase Is Involved in Disulfide Bond
Formation in FK228 Anticancer Depsipeptide. Chem. Biol. Elsevier Ltd; 2009; 16:585-93. Available from: http://dx.doi.org/10.1016/j.chembiol.2009.05.005

28. Nivala O, Mattinen ML, Faccio G, Buchert J, Kruus K. Discovery of novel secreted fungal sulfhydryl oxidases with a plate test screen. Appl Microbiol Biotechnol. 2013;97:9429-37. Available from: http://dx.doi.org/10.1007/ s00253-013-4753-9

29. Suihko M-L. VIT culture collection catalogue of strains. 4th ed. Espoo: VTT; 1999. Available from: http://culturecollection.vtt.fi/m/html?p=m

30. Shevchenko A, Wilm M, Vorm O, Mann M. Mass spectrometric sequencing of proteins from silver-stained polyacrylamide gels. Anal Chem. 1996;68: 850-8. Available from: http://dx.doi.org/10.1021/ac950914h

31. Poutanen M, Salusjärvi L, Ruohonen L, Penttilä M, Kalkkinen N. Use of matrix-assisted laser desorption/ionization time-of-flight mass mapping and nanospray liquid chromatography/electrospray ionization tandem mass spectrometry sequence tag analysis for high sensitivity identification of yeast proteins separated by tw. Rapid Commun Mass Spectrom. 2001;15: 1685-92. Available from: http://dx.doi.org/10.1002/rcm.424

32. Ellman GL. Tissue sulfhydryl groups. Arch Biochem Biophys. 1959;82:70-7. Available from: http://dx.doi.org/10.1016/0003-9861(59)90090-6

33. Raje S, Glynn NM, Thorpe C. A continuous fluorescence assay for sulfhydryl oxidase. Anal Biochem. 2002;307:266-72. Available from: http://dx.doi.org/ 10.1016/S0003-2697(02)00050-7

34. Faccio G, Kruus K, Buchert J, Saloheimo M. Secreted fungal sulfhydryl oxidases: sequence analysis and characterisation of a representative flavindependent enzyme from Aspergillus oryzae. BMC Biochem. 2010;11:31. Available from: http://dx.doi.org/10.1186/1471-2091-11-31

35. Kay LE, Keifer $P$, Saarinen T. Pure absorption gradient enhanced Heteronuclear single quantum correlation spectroscopy with improved sensitivity. J Am Chem Soc. 1992;114:10663-5. Available from: http://dx. doi.org/10.1021/ja00052a088

36. Braunschweiler L, Ernst RR. Coherence transfer by isotropic mixing: application to proton correlation spectroscopy. J Magn Reson. 1969:53:521-8. Available from: http://dx.doi.org/10.1016/0022-2364(83)90226-3

37. Koivistoinen OM, Arvas $M$, Headman JR, Andberg M, Penttilä $M$, Jeffries TW, et al. Characterisation of the gene cluster for L-rhamnose catabolism in the yeast Scheffersomyces (Pichia) stipitis. Gene. Elsevier B.V.; 2012:492:177-85. Available from: http://dx.doi.org/10.1016/j.gene.2011.10.031

38. Arvas M, Kivioja T, Mitchell A, Saloheimo M, Ussery D, Penttila M, et al. Comparison of protein coding gene contents of the fungal phyla Pezizomycotina and Saccharomycotina. BMC Genomics. 2007:8:325. Available from: http://dx.doi.org/10.1186/1471-2164-8-325

39. Grigoriev IV, Nordberg H, Shabalov I, Aerts A, Cantor M, Goodstein D, et al. The genome portal of the Department of Energy Joint Genome Institute. Nucleic Acids Res. 2011;40:D26-32. Available from: http://dx.doi.org/10.1093/nar/gkr947

40. Katoh K, Standley DM. MAFFT multiple sequence alignment software version 7: improvements in performance and usability. Mol Biol Evol. 2013; 30:772-80. Available from: http://dx.doi.org/10.1093/molbev/mst010

41. Capella-Gutiérrez S, Silla-Martínez JM, Gabaldón T. trimAl: a tool for automated alignment trimming in large-scale phylogenetic analyses. Bioinformatics. 2009; 25:1972-3. Available from: http://dx.doi.org/10.1093/bioinformatics/btp348

42. Price MN, Dehal PS, Arkin AP. FastTree 2 - approximately maximumlikelihood trees for large alignments. PLoS One. 2010;5:e9490. Available from: http://dx.doi.org/10.1371/journal.pone.0009490

43. Hoffmeister D, Keller NP. Natural products of filamentous fungi: enzymes, genes, and their regulation. Nat Prod Rep. 2007;24:393-416. Available from: http://dx.doi.org/10.1039/b603084j

44. Scharf DH, Heinekamp T, Remme N, Hortschansky P, Brakhage AA, Hertweck C. Biosynthesis and function of gliotoxin in Aspergillus fumigatus. Appl Microbiol Biotechnol. 2012;93:467-72. Available from: http://dx.doi.org/10. 1007/s00253-011-3689-1

45. Mukherjee PK, Horwitz BA, Kenerley CM. Secondary metabolism in Trichoderma - a genomic perspective. Microbiology. 2012;158:35-45. Available from: http:// dx.doi.org/10.1099/mic.0.053629-0

46. Chivers PT, Prehoda KE, Raines RT. The CXXC motif: a rheostat in the active site. Biochemistry. 1997;36:4061-6. Available from: http://dx.doi.org/10.1021/ bi9628580

47. Quan S, Schneider I, Pan J, Von Hacht A, Bardwell JCA. The CXXC motif is more than a Redox rheostat. J Biol Chem. 2007;282:28823-33. Available from: http:// dx.doi.org/10.1074/jbc.M705291200

48. Scharf DH, Groll M, Habel A, Heinekamp T, Hertweck C, Brakhage AA, et al. Flavoenzyme-catalyzed formation of disulfide bonds in natural products. 
Angew Chem - Int Ed. 2014;53:2221-4. Available from: http://dx.doi.org/10 1002/anie.201309302

49. Li B, Walsh CT. Streptomyces clavuligerus $\mathrm{HIml}$ is an Intramolecular disulfide-forming Dithiol Oxidase in Holomycin biosynthesis. Biochemistry. 2011;50:4615-22. Available from: http://dx.doi.org/10.1021/bi200321c

50. Dolan SK, O'Keeffe G, Jones GW, Doyle S. Resistance is not futile: gliotoxin biosynthesis, functionality and utility. Trends Microbiol. Elsevier Ltd; 2015;23: 419-28. Available from: http://dx.doi.org/10.1016/j.tim.2015.02.005

51. Scharf DH, Remme N, Heinekamp T, Hortschansky P, Brakhage AA, Hertweck C. Transannular Disulfide Formation in Gliotoxin Biosynthesis and Its Role in Self-Resistance of the Human Pathogen Aspergillus fumigatus. 2010;132: 10136-41. Available from: http://dx.doi.org/10.1021/ja103262m

52. Brakhage AA. Regulation of fungal secondary metabolism. Nat. Rev. Microbiol. Nat Publ Group. 2013;11:21-32. Available from: http://dx.doi.org/10.1038/ nrmicro2916

53. Schwarzer D, Finking R, Marahiel MA. Nonribosomal peptides: from genes to products. Nat Prod Rep. 2003;20:275-87. Available from: http://dx.doi.org/10. 1039/b111145k

54. Samson RA, Noonim P, Meijer M, Houbraken J, Frisvad JC, Varga J. Diagnostic tools to identify black aspergilli. Stud Mycol. 2007;59:129-45. Available from: http://dx.doi.org/10.3114/sim.2007.59.13

55. Wang $H, X u Z$ Z, Gao L, Hao B. A fungal phylogeny based on 82 complete genomes using the composition vector method. BMC Evol Biol. 2009;9:195. Available from: http://dx.doi.org/10.1186/1471-2148-9-195

\section{Submit your next manuscript to BioMed Central} and we will help you at every step:

- We accept pre-submission inquiries

- Our selector tool helps you to find the most relevant journal

- We provide round the clock customer support

- Convenient online submission

- Thorough peer review

- Inclusion in PubMed and all major indexing services

- Maximum visibility for your research

Submit your manuscript at www.biomedcentral.com/submit 